Original Research Paper

\title{
Penataan Lahan Pekarangan Untuk Mendukung Budidaya Lebah Madu di Desa Gelangsar, Kabupaten Lombok Barat
}

\author{
Baiq Farista $^{1}$, Arben Virgota ${ }^{1}$, Suripto ${ }^{1}$, A. Jupri ${ }^{1}$, Rina Kurnianingsih ${ }^{2}$, Nur Indah Julisaniah ${ }^{2}$ \\ ${ }^{I}$ Program Studi Ilmu Lingkungan, Fakultas MIPA, Universitas Mataram; \\ ${ }^{2}$ Program Studi Biologi, Fakultas MIPA, Universitas Mataram.
}

https://doi.org/10.29303/jpmpi.v3i2.1111

Sitasi: Farista, B., Virgota, A., Suripto., Jupri, A., Kurnianingsih, R \& Julisaniah, I. (2021). Penataan Lahan Pekarangan Untuk Mendukung Budidaya Lebah Madu di Desa Gelangsar, Kabupaten Lombok Barat. Jurnal Pengabdian Magister Pendidikan IPA 4(4)

Article history

Received: 02 Oktober 2021

Revised: 20 Oktober 2021

Accepted: 07 November 2021

*Corresponding Author: Baiq Farista, Program Studi Ilmu Lingkungan, Fakultas MIPA, Universitas Mataram;

Email: bfarista@unram.ac.id

\begin{abstract}
The resident's yard of Gelangsar Village generally has not been used optimally. In some parts of the yard are overgrown with shrubs whose benefits are not yet known. This program aims to introduce yard management methods that can provide economic benefits, namely the innovation of flowering plant gardens to support honey bee cultivation. The method used in this program is socialization and the formation of a pilot project. The socialization focused on introducing the arrangement of the yard with flowering plants. The pilot project was made on the land of one of the partner residents. In this pilot project, innovations in planting flowering plants with vertical garden and honey bee cultivation methods are applied. Through this pilot method, it is hoped that the people of Gelangsar Village can apply the innovations offered independently. This program has been successfully implemented. Partner residents are willing to apply the innovation of a combination of flowering plant gardens and honey bee cultivation.
\end{abstract}

Keywords: Land arrangement; Yard; Cultivation; Honey bee.

\section{Pendahuluan}

Desa Gelangsar merupakan salah satu desa yang terletak di Kabupaten Lombok Barat dengan ketinggian sekitar 1.000 meter dari permukaan laut yang memiliki topografi daerah bukit berbaris. Bukit Bintang Tiga Rasa di Dusun Songoran merupakan salah satu dari tiga bukit berjajar di desa Gelangsar yang saat ini menjadi objek wisata andalan yang tengah naik daun. Terdapat juga air terjun Geripak atau Timponan dengan ketinggian 35 meter dengan kolam membundar selebar 15 meter yang diapit oleh perbukitan dan pepohonan. Selain panorama alamnya, desa Gelangsar juga menjadikan kekayaan alamnya berupa buah-buahan sebagai salah satu daya tarik untuk meningkatkan minat wisatawan.
Di sisi lain, lingkungan permukiman penduduk belum tertata dengan baik. Lahan pekarangan belum dimanfaatkan dengan optimal. Pemandangan lahan pekaragan seperti ini tidak dapat diabaikan dan perlu segera diperbaiki guna mendukung pengembangan Desa Wisata di Desa Gelangsar. Lingkungan dan pekarangan yang belum tertata menyebabkan nilai estetika lingkungan rendah sehingga dapat mengurangi nilai daya tarik wisata di Desa Gelangsar.

Penataan lahan pekarangan menjadi gambaran perhatian masyarakat terhadap keindahan dan kebersihan lingkungan. Lahan pekarangan yang belum tertata menunjukkan bahwa pengetahuan dan keterampilan masyarakat Desa Gelangsar mengenai teknik penataan lahan pekarangan masih sangat terbatas. Menurut Arifin et al. (1997) dalam Azra, et al. (2017) Pekarangan merupakan sebidang lahan yang berada di sekitar rumah dengan status 
kepemilikan pribadi dan memiliki batas-batas yang jelas, baik berupa tembok, pagar besi, pagar tanaman tergantung pada adat, kebiasaan, sosialbudaya masyarakat, status ekonomi, lokasi pekarangan, dan lain-lain. Lahan pekarangan yang relatif sempit namun memiliki banyak fungsi diantaranya sebagai penghasil bahan pangan, area berternak dan juga taman. Lahan pekarangan yang termanfaatkan dengan baik dapat memberikan nilai tambah seperti pemenuhan gizi keluarga dan juga menambah pendapatan keluarga (Junaidah, et al., 2017).

Salah satu upaya pemanfaatan lahan pekarangan untuk dapat meningkatkan pendapatan keluarga dan juga sekaligus meningkatkan estetika pemukiman penduduk adalah dengan budidaya lebah madu. Madu yang dihasilkan oleh lebah memiliki nilai ekonomis yang tinggi. Permintaan pasar terhadap madu lombok terus meningkat. Permintaan pasar ini seringkali tidak dapat terpenuhi karena terbatasnya stok madu yang tersedia (SuaraNTB.com, 2021). Oleh sebab itu, pengabdian kepada masyarakat ini dilaksanakan untuk mendukung budidaya lebah madu di Desa Gelangsar Lombok Barat melalui penataan lahan pekarangan dengan taman tanaman hias pakan lebah madu. Taman pakan lebah madu yang tertata dan tersusun atas beragam tanaman hias beraneka warna dapat meningkatkan keindahan pemandangan pekarangan.

\section{Metode}

Kegiatan penataan lahan pekarangan untuk mendukung budidaya lebah madu ini dilaksanakan di Dusun Gelangsar, Desa Gelangsar, Kabupaten Lombok Barat pada bulan Juli - Oktober 2021. Kegiatan ini dilaksanakan dengan menggunakan metode sosialisasi dan pembentukan pilot project (proyek percontohan). Sosialisasi dilaksanakan untuk mengajak warga Dusun Gelangsar menata lahan pekarangan dengan tanaman berbunga dan menyampaikan informasi mengenai prospek ekonomi pengembangan budidaya lebah madu. Pilot project dibuat di lahan pekarangan salah satu warga sebagai percontohan. Pilot project ini meliputi penataan taman dengan tanaman hias pakan lebah madu dan praktik budidaya lebah madu.

\section{Hasil dan Pembahasan}

Lahan pekarangan penduduk Dusun Gelangsar umumnya belum dimanfaatkan dengan optimal. Pada beberapa bagian dari lahan pekarangan ini masih kosong dan ada pula yang hanya ditumbuhi oleh tumbuhan liar. Beberapa ide muncul dari masyarakat setempat untuk pemanfaatan lahan pekarangan ini, salah satunya adalah pengembangan budidaya lebah madu. Secara alami, Desa Gelangsar sangat potensial untuk budidaya lebah madu. Di sekitar Desa Gelangsar banyak ditumbuhi oleh tanaman yang disukai oleh lebah madu. Beberapa jenis tanaman pakan lebah madu adalah bunga mangga, pisang, rambutan, nangka, belimbing (De Lima, et al., 2019). Tanaman buah ini umum di temukan di lahan pekarangan Desa Gelangsar.

Kegiatan pengabdian ini diawali dengan sosialisasi tentang penataan lahan pekarangan. Perserta terdiri dari karang taruna, kelompok sadar wisata (Pokdarwis) desa Gelangsar, perangkat desa, dan perwakilan warga dari masing- masing dusun.

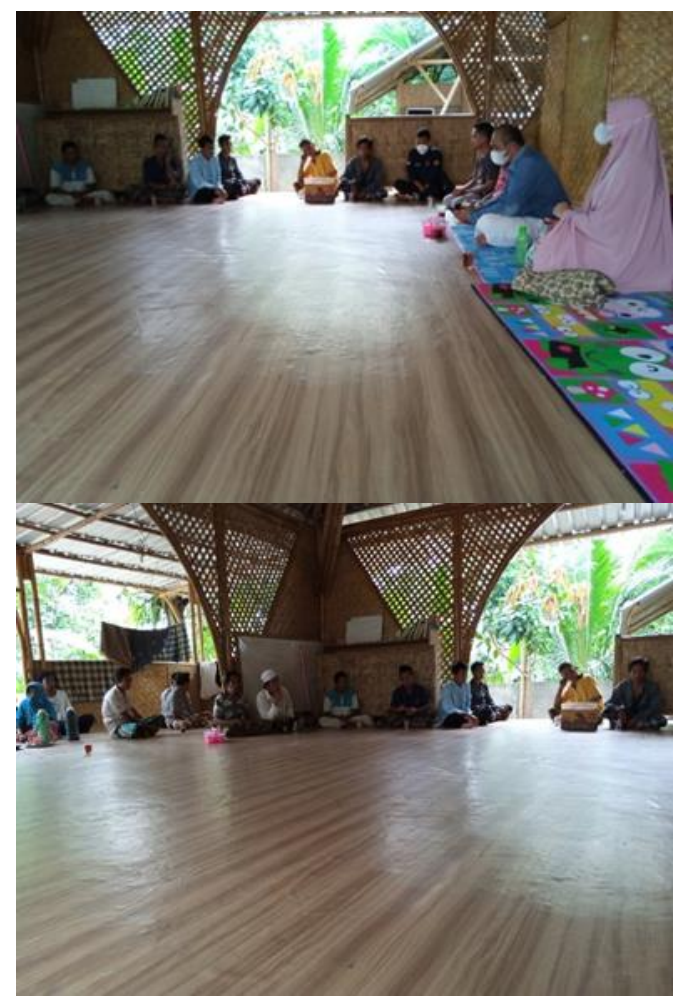

Gambar 1. Kegiatan sosialisasi penataan lahan pekarangan 
Penataan lahan pekarangan untuk mendukung budidaya lebah madu diaplikasikan pada pekarangan rumah salah satu penduduk sebagai pilot project (percontohan). Diharapkan melalui percontohan ini masyarakat sekitar tertarik untuk menata halamannya agar terlihat indah dan memberikan nilai ekonomi. Pada lokasi percontohan dibuat vertical garden dan juga taman horizontal, yang berisikan tanaman hias pakan lebah madu. Ketersediaan pakan menjadi faktor yang sangat penting diperhatikan dalam budidaya lebah madu. Kekurangan pakan dapat menyebabkan menurunnya produksi madu (Agussalim, et al., 2017). Oleh sebab itu, untuk menjamin keberlanjutan ketersediaan pakan lebah madu dan juga untuk meningkatkan nilai estetika pekarangan maka dibuat taman pakan lebah madu.

Alat dan bahan penataan taman menggunakan bahan yang mudah didapatkan dengan harga yang relatif murah sehingga tidak menyulitkan warga ketika ingin menerapkan di pekarangan masing-masing. Teknik vertikal garden yang diterapkan dapat mengurangi sampah plastik seperti botol plastik bekas yang dapat dimanfaatkan sebagai tempat untuk media tanam. Media tanam dapat diperoleh dari hasil kompos pada teknik lubang resapan biopori sehingga warga tidak perlu mengeluarkan modal banyak saat mencoba di rumah masing- masing. Bibit tanaman hias yang digunakan diperoleh dari perbanyakan tanaman hias yang sudah ada. Bibit disemai dalam polibag. Bibit yang digunakan terdiri atas beberapa jenis tanaman hias yang potensial sebagai pakan lebah. Beberapa diantaranya adalah bunga soka, krokot, santos, lantana, dll. Hampir semua tanaman yang berbunga merupakan sumber pakan lebah madu. Pakan lebah madu adalah nektar dan pollen yang terdapat pada bunga dan air. Bunga dari tanaman-tanaman tersebut mengandung nektar dan pollen (De Lima, et al., 2019). Tumbuhan berbunga menghasilkan pemandangan yang indah pada lahan pekarangan warga. Beberapa jenis tanaman berbungan yang digunakan untuk membuat taman pada kegiatan pengabdian ini adalah Krokot (Portulaca grandiflora), Lantana (Lantana camara), Kembang Kertas (Zinnia peruviana), Soka (Ixora coccinea), Santos (Xanthostemon chrysanthus), bunga Lily (Zephyranthes rosea) dan bunga seribu bintang (Chupea hyssopifilia). Tanaman berbunga ini ditata di lahan pekarangan dan juga dengan teknik vertical garden.

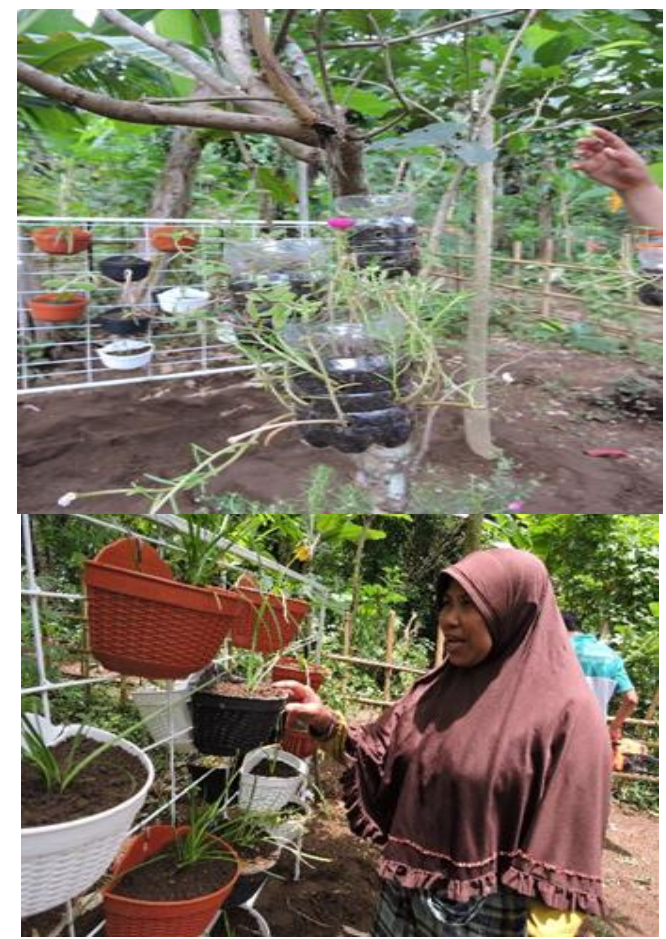

Gambar 2. Penataan tanaman berbunga di lahan pekarangan

Kegiatan pengabdian ini dilanjutkan dengan mempersiapkan peralatan dan bahan-bahan untuk budidaya lebah madu. Beberapa peralatan dan bahan yang digunakan adalah koloni lebah madu yang diperoleh dari komunitas petani lebah madu. Koloni lebah madu ini bersarang pada batang pohon. Beberapa koloni lebah madu yang ada di batang pohon ini ada yang dipindahkan ke stup. Stup merupakan sarang lebah yang dibuat dari papan yang berbentuk kotak. Sarang lebah madu dalam budidaya terbagi menjadi dua macam yaitu sarang alami berupa batang pohon (log kayu) dan sarang buatan berupa kotak kayu (stup) (Achyani \& Wicandra, 2019).

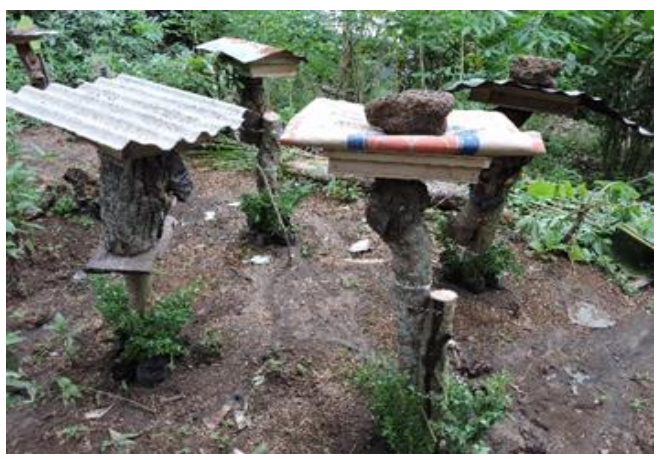




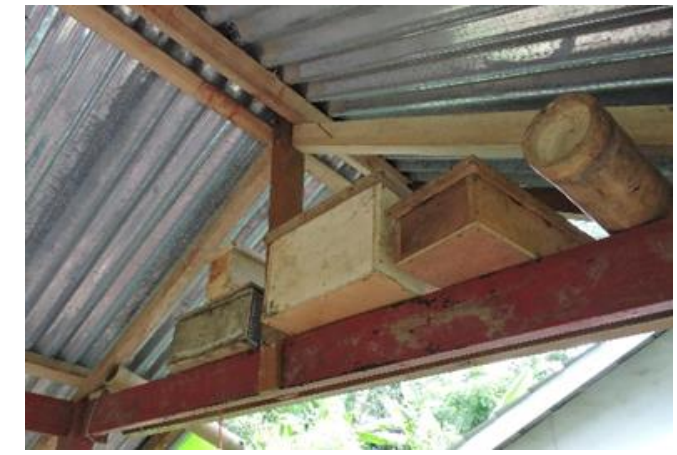

Gambar 3. Koloni lebah madu yang dibudidayakan

Budidaya lebah madu di lahan pekarangan disertai dengan taman tanaman berbunga menambah nilai daya tarik Dusun Gelangsar sebagai desa wisata. Selain itu, budidaya lebah madu dapat menjadi salah satu atraksi wisata yang dapat ditawarkan kepada calon wisatawan. Warga Dusun Gelangsar sebagai mitra dalam kegiatan pengabdian ini merasakan manfaat dari penerapan inovasi yang ditawarkan. Mitra sangat optimis inovasi ini dapat memberikan nilai ekonomi yang tinggi di kemudian hari. Inovasi ini dirasakan sangat sederhana dan mudah untuk diterapkan.

\section{Kesimpulan}

Program pengabdian pada masyarakat ini dapat diterima dengan baik oleh mitra. Mitra bersedia untuk menjaga keberlangsungan dari pilot project ini hingga dapat memberikan hasil atau manfaat ekonomi. Mitra juga bersedia untuk berbagi pengalaman dengan warga yang lain yang berminat dalam penerapan inovasi ini.

\section{Ucapan Terima Kasih}

Tim pengabdian mengucapkan terimakasih kepada Lembaga Penelitian dan Pengabdian Kepada Masyarakat (LPPM) Universitas Mataram, Kepala Dusun/Desa Gelangsar, Warga Mitra dan Mahasiswa Program Studi Ilmu lingkungan dan Program Studi Biologi FMIPA Universitas Mataram yang telah mendukung terlaksananya program pengabdian ini.

\section{Daftar Pustaka}

Achyani, \& Wicandra, D. (2019). Kiat Praktis Budidaya Lebah Trigona (Heterotrigona itama). CV. Laduny Alifatama.
Agussalim, A., Agus, A., Umami, N., \& Budisatria, I. G. S. (2017). Variation of Honeybees Forages As Source of Nectar and Pollen Based on Altitude in Yogyakarta. Buletin Peternakan, 41(4), 448. https://doi.org/10.21059/buletinpeternak.v41i4. 13593

Analysis, C., Food, S., Diversification, C., \& Regency, B. (2017). Analisis Karakteristik Pekarangan dalam Mendukung Penganekaragaman Pangan Keluarga di Kabupaten Bogor. Jurnal Lanskap Indonesia, 6(2), 1-12. https://doi.org/10.29244/jli.2014.6.2.1-12

De Lima, D., Lamerkabel, J. S. A., \& Welerubun, I. (2019). INVENTARISASI JENIS-JENIS TANAMAN PENGHASIL NEKTAR DAN POLEN SEBAGAI PAKAN LEBAH MADU Apis mellifera DI KECAMATAN KAIRATU KABUPATEN SERAM BAGIAN BARAT. Agrinimal Jurnal Ilmu Ternak Dan Tanaman, 7(2), $77-82$. https://doi.org/10.30598/ajitt.2019.7.2.77-82

Farista, B., Virgota, A., Candri, D. A., Ahyadi, H., \& Jupri, A. (2020). Pelatihan dan Sosialisasi Inovasi Vertikultur Dalam Pemanfaatan Hasil Pengolahan Sampah Rumah Tangga Di Desa Kembang Kuning Lombok Timur. Jurnal Pengabdian Magister Pendidikan IPA, 2(2). https://doi.org/10.29303/jpmpi.v2i2.375

Junaidah, J., P.Suryanto, P. S., \& Budiadi, B. (2017). KOMPOSISI JENIS DAN FUNGSI PEKARANGAN (Studi kasus desa Giripurwo, Kecamatan Girimulyo, DI Yogyakarta). Jurnal Hutan Tropis, $\quad 4(1), \quad 77$ https://doi.org/10.20527/jht.v4i1.2884

SuaraNTB.com. (2021). Petani Lebah Madu Trigona di Lobar Kewalahan Penuhi Permintaan Pembeli | SuaraNTB. Retrieved October 4, 2021, from https://www.suarantb.com/petani-lebah-madutrigona-di-lobar-kewalahan-penuhi-permintaanpembeli/ 